ORIGINAL ARTICLE

\title{
The Effect of Hypertension on Hearing Sense
}

\author{
Achmad Chusnu Romdhoni ${ }^{1 *}$ \\ ${ }^{1}$ Department of Otorhinolaryngology-Head and Nech Surgery, Faculty of Medicine, Universitas Airlangga - Dr. Soetomo \\ General Hospital Surabaya, Indonesia
}

\author{
A R T I C L E I N F O \\ Article history: \\ Received 2 May 2018 \\ Received in revised form 21 May \\ 2018 \\ Accepted 28 May 2018 \\ Available online 30 April 2018 \\ Keywords: \\ Hypertension \\ Hearing loss \\ Increased blood pressure \\ Deafness prevalence. \\ *) Corresponding author: \\ romdhoni-a-c@fk.unair.ac.id
}

\begin{abstract}
A B S T R A C T
Hypertension is an important health problem because of its high prevalence and can cause damage to target organs. The relationship between hypertension and hearing loss is not difficult to understand, when blood pressure becomes high blood vessel damage occurs. Hearing loss cases caused by hypertension are considerable, in America 64 million people aged 18 to 75 years suffer from hypertension, $40 \%$ with hearing loss. This damage is not centered on one area of the body, but the whole body is also affected, including the ears. The incidence of hearing loss in hypertension is due to the occurrence of inner ear damage due to high pressure in the vascular system, changes in microcirculation and the occurrence of ionic changes.
\end{abstract}

\section{Introduction}

Hypertension is an important health problem because it has a high prevalence and can cause damage to target organs. One of the target organ damage by hypertension is the hearing system that causes hearing loss that can affect the quality of life of a person (1).

The relationship between hypertension and hearing loss is not difficult to understand, when blood pressure becomes high, it damaged blood vessels. This damage is not only centered on one area, but also the whole body, including the ears (2) Hearing loss cases caused by hypertension are quite high, in America 64 million people aged 18 to 75 years suffer from hypertension, $40 \%$ has hearing loss, only $68 \%$ are aware of the disease, $53 \%$ seek treatment and only $27 \%$ can be well controlled. $(1,3)$ Hypertensive patients are strongly encouraged to check their hearing immediately to ensure their hearing conditions, therefore good cooperation between cardiologist and otolaryngologist is needed (2). This review aim for better understanding of the hypertension effect on hearing sense.

\section{Cochlear Anatomy}

Generally, the ear is divided into three parts, namely the outer ear, middle ear and inner ear (Figure 1) The inner ear consists of a cochlea, a two-and-a-half circle and vestibular consisting of three semicircular canals. At the tip or top of the cochlea is called helicoterma, connecting a tympanic perilymph with a vestibular scale. In the cochlear transverse section, the vestibule scale appears at the top, the tympanic scale at the bottom and the media scale is between them. The vestibule scale and the tympanic scale contain perilymph, while the media scale contains endolymph(4).

Biomolecular and Health Science Journal 


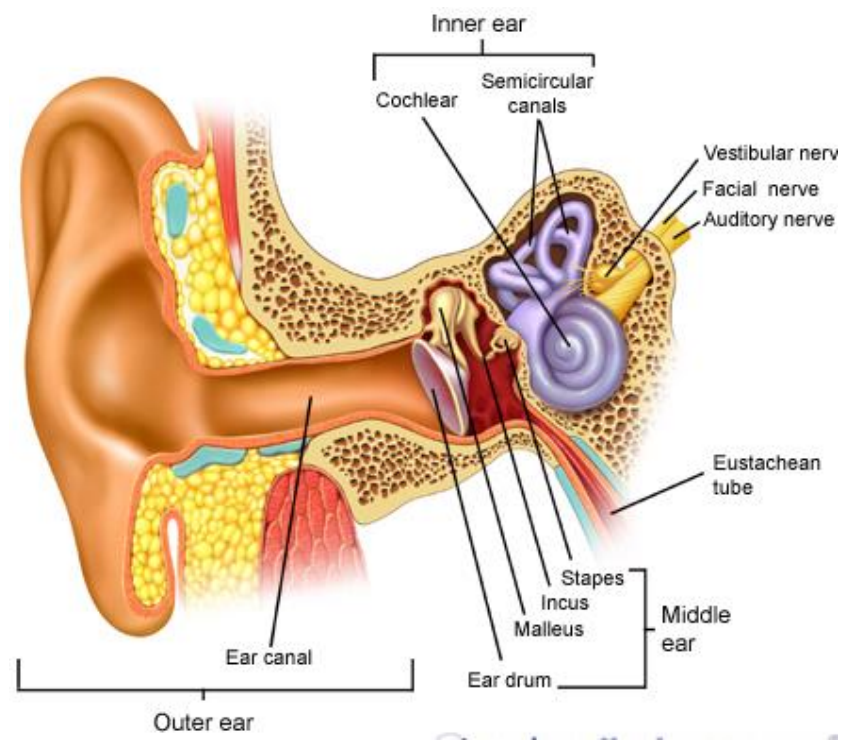

Figure 1. Hearing organ anatomy (19)

The electrolyte or ionic liquids present on perilymph differ from endolymphs. The base of the vestibule scale is called the vestibular membrane or the Reissner's membrane, whereas the base of the media scale is the basal membrane contained by the Corti organ. The media scale has a section called the tectorial membrane, in a basal cell membrane attached to a hair cell comprising an outer hair cell and an inner hair cell and a Corti canal that forms a Corti organ $(4,5)$.

Outer hair cells and inner hair cells in the cochlea are two types of special cells that are sensitive to mechanical motion (mechano-sensitive cells) and arise from sound stimulation. Both types of cells have a role in mechanical energy transfer mechanisms as acoustics into electric potential energy in the form of nerve conduction (4).

Hair cells have shape of pumpkin-fruit like, on the stereocilia small number of hair cells existed, composed of three to four lines, there is no attachment to the tectorial membrane, where the position of the nucleus in the middle with the spread of cytoplasmic organelles (Figure 2) (6). The main function of deep hair cells is to pass the sound information into the brain while the outer hair cells play a role in the amplification of cochlear amplifiers, and sensitivity to frequency or sharp tuning (7).

The discovery of experimental research both in vitro and in vivo found consistent results that the outer hair cell electromotility revealed the role of cochlear amplifier that functioned against the cochlear ability to distinguish different types of frequencies and to understand complex speech sounds because the outer hair cells have special intra cell components such as subsurface cisternae so that the outer hair cells may change in size when the mechanical process is mechanized (7).

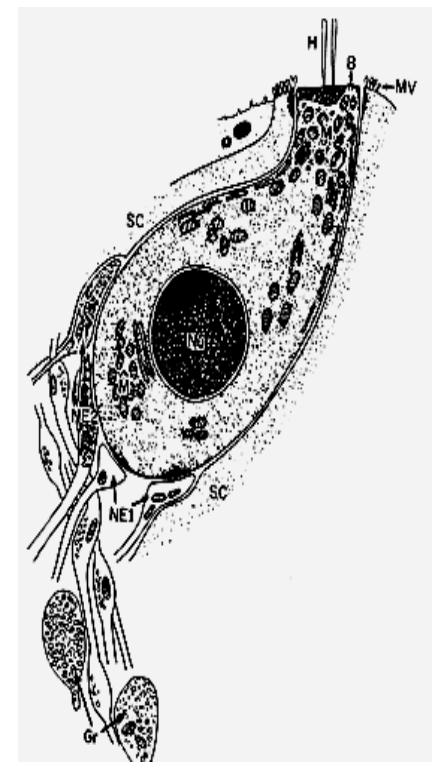

Figure 2. Ultrastructure of hair cell anatomy (6)

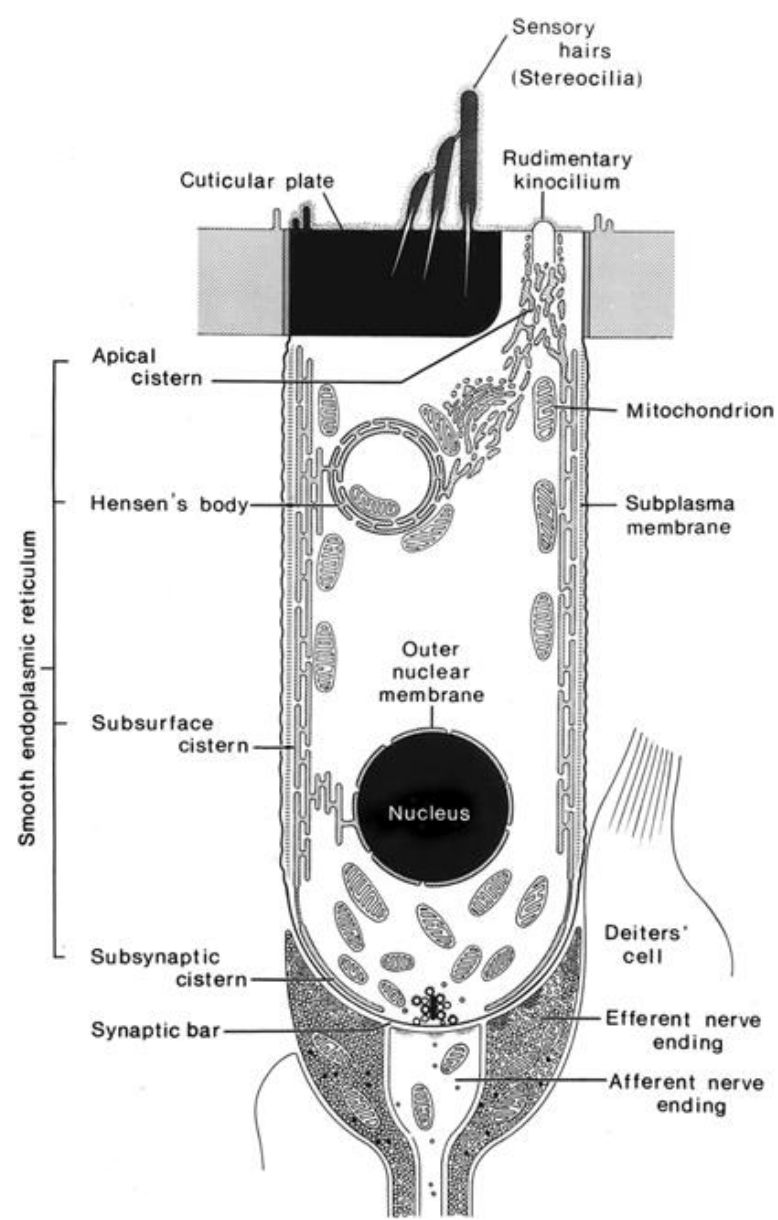

Figure 3. Ultrastructure of outer hair cell anatomy (5)

The outer hair cell shape is cylindrical with a diameter of $9 \mu \mathrm{m}$ with a length size varying between less than $15 \mu \mathrm{m}$ for outer hair cells found in the cochlear basal to more than $90 \mu \mathrm{m}$ in the cochlear apex. The outer 
hair cells of the basement are hemisphere-shaped and supported by the Deiter cell in which there is a nucleus cell, at the bottom of the nucleus cell is found synapses derived from afferent and efferent nerve fibers. In outer hair cells found more efferent nerve fibers and there are only 5\% afferent nerve fibers (figure 3) (5).

Although it has only a few afferent nerves, outer hair cells have a great role in the ability to hear. At the top of outer hair cells there are cuticular plate and stereocilia. Stereocilia is a microvilli in the form of protrusion of plasma cell membrane and contains actin filament (F-actin) with function to retain its shape while stereocilia base is immersed in cytoskeletal filament matrix called cuticular plate (8).

The outer hair cell contains about 130-150 stereocilia with a diameter about $145 \mathrm{~nm}$ arranged in 3 rows resembling the letter $\mathrm{W}$ or $\mathrm{V}$ with different height arranged like a ladder. At the tip of the highest stereocilia, in a membrane composed of gelatin fibers and a transparent matrix called the tectorial membrane (Fig. 4) (8).

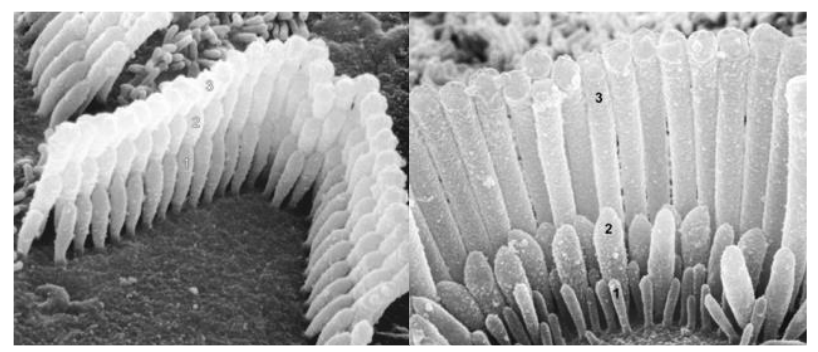

Figure 4. Ultrastructure of stereocillia anatomy(8)

Stereocilia are interconnected at the top and sides of the extracellular filaments that form a bridge or cross bridges called tip links and side links. The cross bridge consists of a pair of protofilaments with a diameter of approximately $5 \mathrm{~nm}$ in size while the length is $150-300$ $\mathrm{nm}$, resembling a twisted rope, in the presence of deflection from stereocilia caused by the motion of shear in the highest sterocilia resulting in all stereocilia can make the movement (9).

Vascularization of the cochlea and vestibule is supplied from the labyrinthine artery (internal auditory artery) originating from the anterior inferior cerebellar artery of the basilar artery branch. There is an anatomical variation in the artery directly from the basilar artery. The labyrinthine artery is derived from the meatal loop or meatal loop of the superior cerebellar artery (figure 5). The arch is attached to the cochlear nerve and may coincide between the cochlear nerve with the facial nerve.(10). The first branch of the labyrinthine artery is the anterior vestibular artery supplying blood to the posterior and lateral semicircular canals, the utricle and the posterior portion of the sacrament. Cochlear vascularization originates from the common cochlear artery and provides branches to the cochlea and vestibular organs (figure 5a-b) (10).

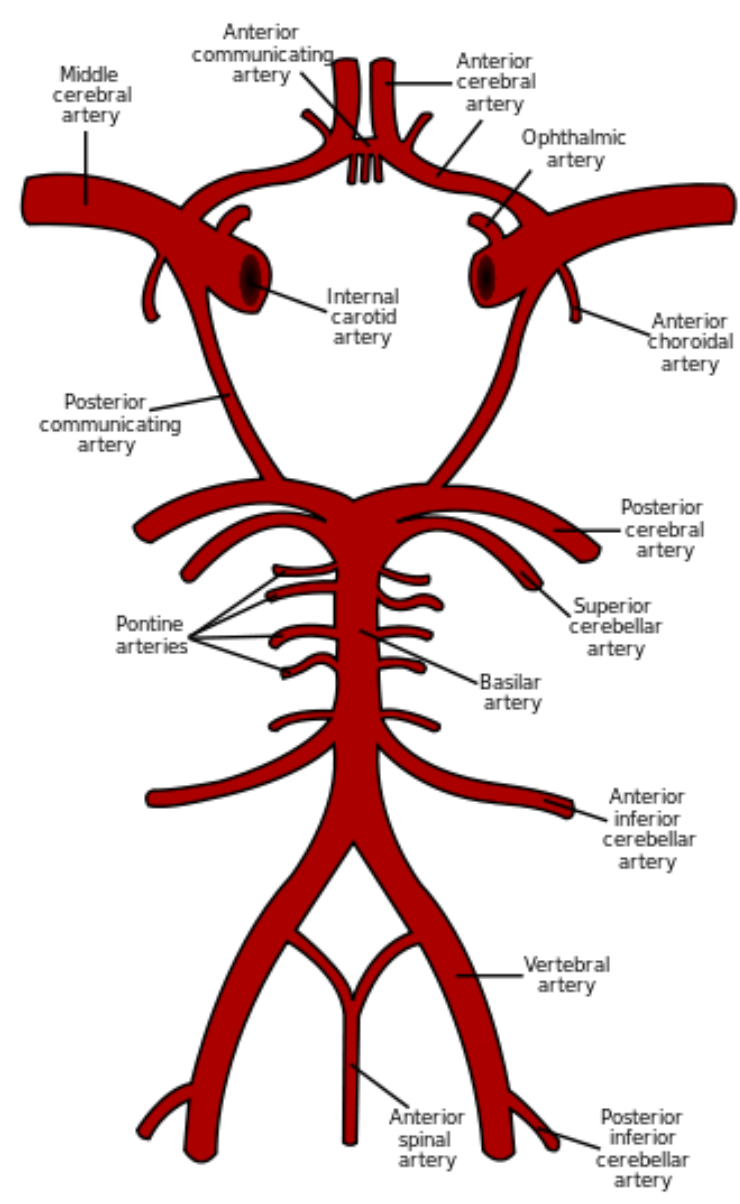

Figure 5a. Cochlea Vascularization (10)

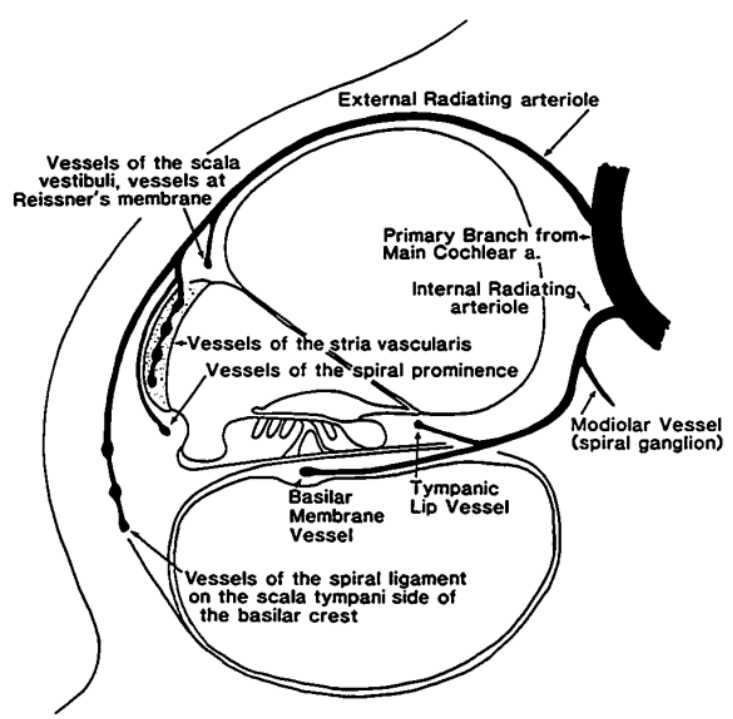

Figure 5b. Cochlea Vascularization (10) 


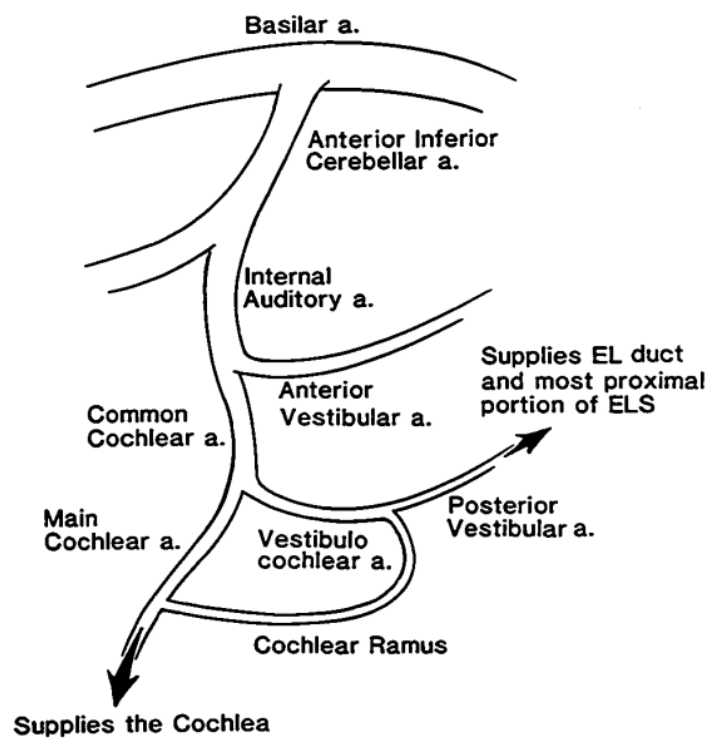

Figure 5c. Cochlea Vascularization (10)

\section{Hearing Physiology}

Physiology of hearing begins from the sound energy or sound in the form of sound waves that captured by the ear leaf and then forwarded to the tympanic membrane and then the tympanic membrane vibrates. The vibration is continued to the hearing bone of maleus, incus and stapes. Stapes moves the foramen ovale. The movement continues into perilymph at the vestibular scale, the vibration is passed through the basal membrane downward and the perilymph in the tympanic scale will move so that the foramen rotundum is pushed outward. The end of the Corti cell hair curves at rest and with the basal membrane pushed the end of the hair cell becomes straight then the physical stimulation is turned into electrical stimulation due to the difference of sodium and potassium ions which are continued on the branches of the cochlear nerve (N. VIII), then stimulation is transmitted to the sensory center of hearing in the brain through the central nerves present in the area 39 and 40 of temporal lobes. $(5,11,12)$

\section{Hypertension}

Hypertension is still a problem in almost all community groups, both in Indonesia and around the world and its prevalence tends to increase, if not addressed properly, there can be a lot of organ damages. Hypertension is defined as an increase in systolic blood pressure $>140$ $\mathrm{mmHg}$ or diastolic pressure $>90 \mathrm{mmHg}$ according to JNC VII.(13)

Blood pressure is determined by two main factors, cardiac output and peripheral vascular resistance. Cardiac output is the result of heartbeat frequency multiply the stroke volume, while the stroke volume is determined by venous return and the strength of myocardial contraction. Peripheral resistance is determined by vascular smooth muscle tone, elasticity of blood vessels and blood viscosity. All these parameters can be affected by several factors, including the sympathetic and parasympathetic nervous system, the renin-angiotensin-aldosterone (RAA) system and local factors of vasoactive substances produced by vascular endothelial cells.(13)

The sympathetic nervous system is precise, which increased blood pressure by increasing heart rate, strengthening myocardial contractility, and increasing blood vessel resistance. Parasympathetic system is the opposite effects. When triggers, it will lower the blood pressure by lowering the frequency of heart rate. The RAA system is also precise because it can trigger the release of angiotensin II which has a vasoconstrictive effect of blood vessels and aldosterone that causes water and sodium retention in the kidney thus increasing blood volume.(13)

Endothelial cells of blood vessels also play an important role in the occurrence of hypertension. Endothelial vascular cells produce a variety of vasoactive substances that are partially vasoconstrictors such as endothelin, A2 thromboxane and local angiotensin II. Some are vasodilators such as endothelium-derived relaxing factor (EDRF), also known as nitric oxide (NO) and prostacyclin (PGI2). The heart especially the right atrium producing a hormone called atrial natriuretic peptide (ANP) is diuretic, natriuretic and vasodilator which tends to lower blood pressure.(13)

\section{Criteria, Classification, and Risk Factors}

According to The Seventh of The Join National Committee on Prevention, Detection, Evaluation, and Treatment of High Blood Pressure (JNC 7) the classification of adult blood pressure is divided into the normal group of SBP (systolic blood pressure) $<120$ $\mathrm{mmHg}$ and DBP (diastolic blood pressure ) $<80 \mathrm{mmHg}$, prehypertension SBP 120 -139 mmHg and DBP 80 - 90 $\mathrm{mmHg}, 1$ degree hypertension SBP 140 - $159 \mathrm{mmHg}$ and DBP 90 - $99 \mathrm{mmHg}$, second-degree hypertension SBP> $160 \mathrm{mmHg}$ and DBP> $100 \mathrm{mmHg}$ hypertension.(14)

Based on the etiology/causes are divided into 2, namely primary, essential or idiopathic hypertension and secondary hypertension. Primary hypertension is unknown hypertension etiology/causes, $90 \%$ of all hypertensive diseases are primary hypertension disease. Secondary hypertension is hypertension that occurs as a result of a disease, condition and habits, therefore generally this hypertension cause has been known for example due to kidney disease, hormonal abnormalities or due to the use of certain drugs(14)

Various hypertension risk factors are: genetics is a descending properties that passed in the family, the Caucasian is likely to suffer from hypertension compared to other races, the increase in age tends to increase blood pressure, men more likely to suffer from hypertension than women, psychological stress increases the activity of nerves sympathetic, obesity causes increased cardiac 
work, sodium salt intake leads to water retention, cigarettes and alcohol consumption.(14)

\section{Pathogenesis}

\section{Primary Hypertension}

The underlying cause of primary hypertension is still unknown but there are several theories that are suspected to be the cause of primary hypertension that is the excessive activity of the sympathetic nervous system and the RAA system, the $\mathrm{Na}$ and water retention by the kidneys and the complex interactions involving endothelial function.(14)

\section{Secondary Hypertension}

Secondary hypertension is caused by a systemic disease process that increases peripheral vascular resistance or cardiac output, for example renovascular or parenchymal disease, adrenocortical tumors, pheochromocytoma and drugs, when the cause is known and curable before structural changes persist, blood pressure can return to normal (14).

\section{Mechanism of Hearing Impairment in Hypertension}

The cochlea is a sensory organ located in the inner ear, much more complex than other sensory organs and is an end-organ in vascularization, the main blood supply by one artery, just like the retina, the heart, and the kidneys. This type of vascularization makes the organ susceptible to reduced blood flow $(15,16)$.

The incidence of hearing loss in hypertension is due to the occurrence of inner ear damage due to high pressure in the vascular system, microcirculation changes and ionic changes (16).

\section{High pressure in the vascular system and microcirculation changes}

Macro vascular changes that occur in hypertension include increased synthesis of connective tissue components, elastin and collagen by smooth muscle cells that lead to thickening of artery walls. Smooth muscle cells in the blood vessel media also undergo changes, such as hyperplasia and hypertrophy. Tunica intima artery in hypertension becomes thicker due to increased size and height of endothelial cells.(15) When blood pressure becomes high, blood suppresses the arteries so quickly that it can cause damage to the lining of the artery walls. In areas affected by damage can form fatty plaque. As age passed, the more damage to the arterial wall, the more fatty plaque that is formed, in which reduce or stop the blood flow, this damage is not centered on one area of the body, but the whole body is also affected, including the ears. (2) All living cells in the human body depend on the adequacy of oxygen and nutrient supply to maintain their function, and that supply depends on the integrity of the structure and function of the heart and blood vessels. Hypertension, the most common vascular disorder that can cause inner ear bleeding, causes progressive or sudden hearing loss (1). Microorganisms in Corti organs can lead to atrophy and reduced hair cells. Neuropathy may also occur due to microangiopathy in N.VIII vessel and spiral ligament vas with the consequence of elucidation of N.VIII fibers and spiral ganglion atrophy. Hair cells can also develop atrophy due to the accumulation of various toxic substances resulting from endolymph metabolism due to disruption of resorption by the blood vessels around the endolymphatic sac (17).

\section{The Occurrence of Ionic Change}

Cochlear membranes can be damaged or torn due to hypertension. The cochlea or inner ear is formed from thin smooth membranes with fluid-filled spaces. The movement of the liquid causes soundwave. The electrical charge is created by the ear by actively storing a special electrolyte in the liquid filled chambers. This active storage of electrolytes makes the difference in charge (+ or -) separated by a thin membrane. The difference in charge between spaces generates nerve impulses such as electricity that arise from positive and negative poles of the battery. Tore of the thin membrane can cause fluid mixing, loss of electrical charge, so it can not generate nerve impulses and cause hearing loss.(18)

\section{Summary}

Hypertension is an important health problem because it has a high prevalence and can cause damage to the hearing system that causes hearing loss that can affect the quality of life. The incidence of hearing loss in hypertension is due to the occurrence of inner ear damage due to high pressure in the vascular system, changes in microcirculation and the occurrence of ionic changes. Patients with hypertension is strongly recommended to check his hearing immediately to ensure his hearing condition, because it needs good cooperation between the cardiologist and otolaryngologists expert.

\section{Conflict of Interest}

The author stated there is no conflict of interest

\section{References}

1. Agarwal S, Mishra A, Jagade M, Kasbekar V, Nagle SK. Effects of hipertension on hearing. Indian J of Otol. 2013;65(3):S615.

2. doctors Ha. 2014. Available from: http://www.hearingaiddoctors.com/news/the-connection-betweenhigh-blood-pressure-and-hearing-loss-1391567808492.html.

3. Waskito H. Faktor-faktor yang mempengaruhi gangguan pendengaran sensorineural pekerja perusahaan minyak. Jurnal Kesehatan Masyarakat Nasional. 2008;2(5):221.

4. Honrubia V, Goodhill V. Clinical anatomy of the peripheral ear In (Goodhill V, ed). : Harper \& Row; 1989.

5. Wright A. Anatomy and ultrastructure of the human ear. London: Butterworths; 1996.

6. Mills JH, Khariwala SS, Weber PC. Anatomy and physiology of hearing. Philadelphia: Lippincott Williams and Wilkins; 2014. 
7. Park MS, Park SW, Choi JH. Distortion product otoacoustic emissions in diabetics with normal hearing. Scandinavian audiology Supplementum. 2001(52):148-51.

8. Yost WA. Fundamental of hearing: an introduction. London: Academic Press; 2000.

9. Dalton DS, Cruickshanks KJ, Klein R, Klein BE, Wiley TL. Association of NIDDM and hearing loss. Diabetes Care. 1998;21(9):1540-4.

10. Kayacan SM, Kazancioglu R, Oflaz H, Tuna S. Comparison of different risk factors that result in endothelial damage leading to diabetic microangiopathy. Southern medical journal. 2003;96(4):387-90.

11. Probst R, Grevers G, Iro H. Anatomy and physiology of the ear. Basic otorhinolaryngology: A step-by-step learning guide. Stuttgart-Germany: Georg Thieme Verlag; 2006.

12. Soetirto. Gangguan pendengaran dan kelainan telinga. In: Soepardi EA, Iskandar N, editors. Buku ajar ilmu kesehatan telinga hidung tenggorok kepala leher. Jakarta: Balai Pustaka FKUI; 2012. p. 5,921.

13. Nafrialdi. Antihipertensi. In: Gunawan SG, editor. Farmakologi dan terapi. Jakarta: Bagian Farmakologi FKUI; 2007. p. 341-60.

14. Yogiantoro M. Hipertensi esensial. In: Sudoyo AW SB, Alwi I, Simadibrata M, Setiati S, editor. Buku ajar ilmu penyakit dalam. Jakarta: Interna Publishing; 2009. p. 1079-85.

15. Goel HC, Moraskar AH, Chodankar S, De'sa C, Goa MG. Effect of systemic hypertension on inner ear functions. National $\mathrm{J}$ of Otorhinolaryngol 2014;2(11):6.

16. Yildirim N. Hearing impairment in vascular disorders. Van Tip Dergisi. 2012;19(3):149-57.

17. Edward Y, Prijadi J. 2009. Available from: www.edward andalas/dm.id.

18. Vanderbilt University Medical Center NU. 2014. [cited 2015]. Available

from: http://www.vanderbilthealth.com/billwilkerson/27939.

19. Sobotta J. Sobotta atlas anatomi manusia. Jakarta: Penerbit Buku Kedokteran EGC; 2013. 